\title{
Analysis of the Use and Integration of the Flipped Learning Model, Project-Based Learning, and Gamification Methodologies by Secondary School Mathematics Teachers
}

\author{
Hossein Hossein-Mohand ${ }^{1, *(\mathbb{D})}$, Juan-Manuel Trujillo-Torres ${ }^{2}\left(\mathbb{D}\right.$, Melchor Gómez-García ${ }^{1}$, \\ Hassan Hossein-Mohand ${ }^{1}$ (D) and Antonio Campos-Soto ${ }^{2}$ (D) \\ 1 Department of Pedagogy, Faculty of Teacher Training and Education, \\ Universidad Autónoma de Madrid (UAM), 28049 Madrid, Spain; melchor.gomez@uam.es (M.G.-G.); \\ hassan.hossein@estudiante.uam.es (H.H.-M.) \\ 2 Department of Didactics and School Organization, Faculty of Educational Sciences, \\ Universidad de Granada (UGR), 18071 Granada, Spain; jttorres@ugr.es (J.-M.T.-T.); \\ acaso4@correo.ugr.es (A.C.-S.) \\ * Correspondence: hossein@centrosd2.com
}

Citation: Hossein-Mohand, H.; Trujillo-Torres, J.-M.; Gómez-García, M.; Hossein-Mohand, H.; Campos-Soto, A. Analysis of the Use and Integration of the Flipped Learning Model, Project-Based Learning, and Gamification Methodologies by Secondary School Mathematics Teachers. Sustainability 2021, 13, 2606. https://doi.org/ $10.3390 /$ su13052606

Academic Editors:

Verónica Marín-Díaz and Juana Ma Ortega Tudela

Received: 18 January 2021

Accepted: 23 February 2021

Published: 1 March 2021

Publisher's Note: MDPI stays neutral with regard to jurisdictional claims in published maps and institutional affiliations.

Copyright: (c) 2021 by the authors. Licensee MDPI, Basel, Switzerland. This article is an open access article distributed under the terms and conditions of the Creative Commons Attribution (CC BY) license (https:/ / creativecommons.org/licenses/by/ $4.0 /)$.

\begin{abstract}
In the didactics of mathematics, many technological resources can be used with teaching strategies, techniques, models, and methodologies that facilitate the teaching-learning process. Pedagogical models such as Flipped Learning and active methodologies such as Project-Based Learning and Gamification have a relevant role in education. Objectives. (1) To identify the variables of teaching practices, ratios, and mathematics teacher training indicators that could influence the choice of different study models or methodologies. Method. A total of 73 teachers from the Autonomous City of Melilla were included in a cross-sectional study. Teachers filled out a validated questionnaire with 35 questions regarding mathematics and teacher training, information and communication technology (ICT) uses, resources and mastery, communication, and collaboration. Results. The statistical analyses revealed significant positive influences between the Flipped Learning model, Project-Based Learning, and Gamification with the evaluated items. Furthermore, Project-Based Learning showed a negative association with two items of the teaching practice indicator. Conclusion. The exchange of information and content through online spaces, participation, and collaboration in center projects related to digital technologies and educational software to teach mathematics had a significant impact on the choice of Flipped Learning model and active methodologies.
\end{abstract}

Keywords: educational technologies; digital competence; active methodologies; Flipped Learning model; Project-Based Learning; Gamification

\section{Introduction}

Didactics is defined as the science of knowledge dissemination and the study of the elements that support it: tasks, techniques, technologies, and a theory that justifies these technologies [1]. In mathematics education, mathematical knowledge, structured in differentiated constructs according to Brousseau and Chevallard's theories, is acquired by learning and solving mathematical problems through the conceptual component of the schemes [2,3].

Even though problem-solving with statements is significantly associated with memory and other cognitive resources, it is one of the greatest difficulties for mathematics students, mainly due to comprehension problems [4]. The elements that most influence problemsolving competence with statements are: textbooks, software, and teachers [4]. There are also differences between the theoretical problems in textbooks and the real problems faced by students in real life. In this sense, the mathematics teacher is essential and must be trained and updated on the use of tools and resources proper to mathematics teaching [5]. 
In mathematics education, pedagogical links between content and technology are established through "instrumental genesis" [6]. This term was coined by Lagrange et al. (2003) to name the transformation from "artifact" to "instrument" [7]. The instrumental genesis for teaching mathematics through technology is a laborious process for the teacher that requires time [8].

In the area of mathematics teaching, a large number of open digital educational resources can be used $[9,10]$, which facilitate the process of teaching and learning [11], favor the development of online communities, and widely promote the dissemination of resources for the mathematics teacher [12]. To promote learning and practice of mathematics and science in general, educational resources are designed with dynamic and attractive programs [13-15]. In this sense, the teacher has the ability and responsibility to properly integrate information and communication technologies (ICT) into mathematics teaching [16].

The use of ICT tools for graphic representation facilitates the collection and interpretation of data and the understanding of mathematical concepts necessary in the learning of science in general, and mathematics in particular [17]. In general, mobile learning environments also allow the implementation of pedagogical strategies for teaching mathematics that are not subject to spatial-temporal limitations [18]. Flexible software learning paths allow teachers to better meet the needs of individual students [14]. As an example, we can cite GeoGebra, the most dynamic mathematics software used worldwide [13,15,19]; however, the use of educational software such as GeoGebra, Maple, MalMath, and Wolfram Alpha is dependent upon the technological skills of the students, the availability of technological resources, or technical limitations (obsolete equipment, internet, etc.).

On the other hand, the combination of technology and pedagogical strategies facilitates critical, systemic, and computational thinking skills, decision making, and problem-solving, which are considered "21st-century skills" [19]. In a technological society in constant evolution, hybrid methods [20-22] and active methodologies have a very relevant role in education because of their special contribution to the teaching-learning process [23,24].

Although there is a wide variety of strategies, pedagogical models, and active methodologies applicable to the teaching of mathematics, in this study, we analyzed Flipped Learning, Project-Based Learning, and Gamification because of their widely developed use in secondary education.

\subsection{Flipped Learning}

The term inverted classroom (IC) was originally coined by [25] and originally used in the teaching of Economics, where the teacher requested an approach to the subject prior to the class [26,27]. In 2012, Bergmann and Sams opted for the term Flipped Classroom model (FCM) [28,29]. Flipped Learning is a pedagogical model that inverts the moments and roles of traditional teaching by transferring certain learning processes to outside the classroom and using class time to facilitate, enhance, and deepen student learning [20]. If it is properly developed, it favors all phases of the learning cycle of Bloom's Taxonomy [30].

Its proper use requires technological resources to approach the contents [22], and although it began in higher education, its use is widespread in American primary schools [31]. Among the benefits, the inverted classroom model allows for the optimization of time, the incorporation of technological resources [32], and the personalization of the teaching and learning processes [23]. In addition, teachers can dedicate more time to diversity, promote collaborative work among the entire educational community $[33,34]$, and provide students with resources at any time for their learning [35].

Different studies show how the Flipped Learning model positively impacts students in secondary education [36-38] and in higher education [39-41]. In addition, positive results are observed in Science, Technology, Engineering, and Mathematics (STEM) education, involving students in experimental environments to encourage learning [42].

Students perceive the usefulness of the Flipped Learning model [43], highlighting its instrumental dimension in the autonomous learning of mathematics [23]. Teachers 
also value the significant improvement of their performance during their training process compared to the traditional models [44] and students' significant progress in terms of their academic performance in mathematics [37]. Despite the positive evaluation, some studies maintain that the effect on the satisfaction of students and teachers is moderated by the necessary dedication [31]. In addition, the literature shows other disadvantages associated with the model, such as stage fright when recording, the new organization of the on-site class, the lack of monitoring by students with low socioeconomic status, and the low self-motivation of students with low academic performance [32].

\subsection{Active Methodologies}

Before starting to address the issue, we could ask the following question: what are active methodologies? One of the possible definitions of active methodologies is "Those methods, techniques, and strategies used by the teacher to convert the teaching process into activities that encourage active student participation and lead to learning" [45]. Based on this definition, active methodologies require continuous learning by teachers in the use of pedagogical strategies [46], technological resources, and Content Pedagogical Technological Knowledge (TPACK) [47].

These methodologies have been significantly developed due to their innovative approach and results in the process of the teaching and learning of students $[48,49]$.

\subsubsection{Project-Based Learning}

The Project-Based Learning methodology (PBL) emerged from the innovative trends of the early 20th century in 1918. William Heart Kilpatrick laid the foundations of this methodology, guided by the "experimental philosophy of education" that guides student learning based on their life experiences [50]. Depending on the purpose, Project-Based Learning is classified into four types: making a final product (Producer's Project); knowing a subject and enjoying its knowledge or experience (Consumer's Project); improving a specific technique or skill (Specific learning); solving an intellectual problem (Problem Project) [51].

Project-Based Learning promotes the active learning of students by strengthening the learning of educational skills in a cross-sectional and multidisciplinary way $[52,53]$ but also integrates values such as cooperation, organization, and time management in a practical way [54]. The direct involvement of students favors creativity, motivation, and the ability to approach challenges in teams from an inclusive perspective [55]. This method can coexist with the traditional teaching-learning system, combining the teacher's expository work with practical collaborative work when developing a concrete project [56].

This system of project implementation is quite common in higher education $[57,58]$. For its implementation in secondary and primary education in Spain, the current educational law (LOMCE-the organic law for improving the quality of education. Organic Law 8/2013, 9 December) includes Project-Based Learning as a tool to enhance learning so that students are able to achieve competence in all subjects. It is considered adequate to motivate students from early ages towards STEM disciplines [59] and also serves as training for the work dynamics that students will follow in their academic and professional future [56]. In a meta-analysis of the period between 1998 and 2017, it is evident that Project-Based Learning presents significant improvements compared to the traditional methodology, although the evaluation depends on educational and geographical factors, available ICT resources, but not on the educational level or the ratio [54].

On the other hand, this methodology requires a high level of dedication and training from the teacher to improve their self-efficacy [60]. In addition, to optimize learning, it is advisable to have projects that have already been elaborated and evaluated, promoting a collaborative dynamic among students [61] and reinforcing the curriculum in a transversal manner with a methodological structure and clear and simple instructions [56]. If the teacher's competence level is adequate, a significant correlation is observed between the students' positive perception of the method [60]. In contrast, no significant positive 
correlation is observed between the methodology employed and the level of creativity, fluency, and originality of the students [57]. Among the possible causes, students cite the lack of time to improve their work [54].

\subsubsection{Gamification}

The next active methodology analyzed in this study was Gamification, defined as "the use of strategies, models, dynamics, mechanics, and elements typical of games in contexts outside these, with the purpose of transmitting a message or some content or change a behavior, through a playful experience that promotes motivation, involvement and fun" [61]. Scientifically, it can be defined as the process of applying game elements to contexts that are not games [62].

Although video games have always had a playful approach, the incorporation of gamification into the educational environment is relatively recent [63], taking into account that the most effective learning methodology for children in Early Childhood Education is focused on games [64], from a constructivist approach to experiential learning, through social interaction with the environment and peers [65]. The gamification is based on "elements" (levels, points, badges, classification tables, unlocking of content, gifts, missions, etc.) [66] that stimulate learning by favoring resilience, learning by repetition, and collaborative and competitive participation [67].

Well designed, the games provide interactive, playful learning environments that facilitate the acquisition of self-directed skills by students [68], improve motivation, and reduce anxiety associated with learning mathematics [69]. With appropriate pedagogical criteria and the guidance of the mathematics teacher, gamification can significantly impact students' mathematical learning [70]. Some improvements are observed in the development of mathematical thinking by students, in the establishment of relationships between mathematical concepts [71], and their academic performance [24]. Given the above reasoning, Gamification can be employed at all academic levels or educational contexts to teach mathematics $[63,71]$.

In the didactics of mathematics, most educational games focus on operations with numbers, algebra, geometry, measurement, data analysis, and probability [46]. Although the number of educational digital games for math learning [24] and programming [72] is significant, evidence-based digital learning games for science in elementary and secondary education are scarce $[66,68]$. Studies support their use in the classroom depending on the available ICT resources [73,74]. It is up to the teacher to effectively incorporate them into the classroom and establish adequate curricular objectives [75]; however, much of the software used in teaching has not been designed to address the difficulties faced by math students [76].

Numerous empirical studies highlight the advantages of learning through Gamification to affect the motivation, autonomy, and digital competence of mathematics students $[25,65,68,76]$. In contrast, other authors argue that Gamification mainly stimulates extrinsic motivation, negatively affecting intrinsic motivation $[66,77,78]$. In other words, students participate in activities to obtain a prize (points, badges, etc.), not for the satisfaction of acquiring new knowledge. On the other hand, in Gamification, a divergence between virtual and real interaction is observed, which can interfere with the students learning process [77]. In addition, the costs derived from educational games and associated technologies can condition their use by teachers in the classroom [68]. However, some authors argue that this methodology should be applied by applying the game mechanics to motivate and involve students even when technological means are not available [66].

On the other hand, the hybrid method and the methodologies analyzed can be integrated and complemented by expanding the pedagogical scope to improve the academic performance of students [78]. 


\subsection{Justification}

Despite the advantages, different authors observe deficiencies from a teaching point of view and recommend using specific evaluation methods that are adapted to the pedagogical Flipped Learning model $[38,39]$ and to active methodologies such as Project-Based Learning [46] and Gamification [68]. In addition, other authors have determined that teaching experience correlates negatively with active methodological approaches [45].

In this context, we propose a transversal analysis of the variables that could affect the use of the Flipped Learning model, Project-Based Learning, and Gamification methodologies through the perceptions of the mathematics teachers from the Autonomous City of Melilla in their teaching practice. The variables of the study correspond to indicator B.2 "Teaching Practice", B.3 "Ratios" of dimension B. "Mathematics and Teacher Training", the items of the indicators C.1 "ICT Training", C.2 "ICT and Teaching", C.5 "Communication and Collaboration" of dimension C, "ICT in the Teachers' Environment", and the items of indicator D.3 "ICT in the Classroom" of dimension D. "ICT Uses, Resources, and Mastery".

The main objective of this study was to identify which technological and academic variables of the above indicators could influence the choice of the pedagogical model and the different methodologies. The following research questions were proposed according to the objective set: RQ1: Which variables of the study have influenced the choice of the pedagogical model and the different analyzed methodologies the most? RQ2: What relation is observed between the variables that had more weight? RQ3: What score did the mathematics teachers assign to the variables of greater impact?

\section{Materials and Methods}

The quasi-experimental method was applied without pre-post and without a control group. The approach of the study was quantitative in order to assess the use of the pedagogical model and the different methodologies of the study by mathematics teachers. In the determination of the population, the following inclusion criterion was used: teaching mathematics in high school in the Autonomous City (A.C.) of Melilla. According to the previous inclusion criterion, the population amounts to 73 teachers, of which, $34.25 \%$ are women. The sample taken includes 61 mathematics teachers, which means $83.56 \%$ of the population, of which $34.42 \%$ are women, guaranteeing the representativeness of the sample. To avoid bias, the questionnaires were conducted covering all the city's centers, and to guarantee the reliability of the data collection, the questionnaires were filled out in an online format using Google Forms. The individuals in the sample were informed about the nature of the study, and they completed the questionnaires during the third quarter of the 2018-2019 school year.

This study's general questionnaire includes 5 dimensions and 23 indicators related to teaching practice and the uses and resources of ICT by mathematics teachers in the A.C. of Melilla. It consists of 107 closed items configured mostly ad hoc with a Likert scale of 4 graduated levels (1: Nothing, 2: Little, 3: Quite, 4: A lot). Experts validated the instrument to determine reliability and validity values. The internal consistency of the data matrix obtained was verified, checking the consistency of the items. The results were optimal since the Tucker-Lewis Index unreliability factor was 0.965 .

The 35 items analyzed in this study relate to the pedagogical model and active methodologies dimension applied by the mathematics teacher and the related items. The items of the model and the methodologies are shown in Table 1. As for the dependent variables, some items of dimensions B. "Mathematics and Teacher Training", C. "ICT in the Teachers' Environment", and D. "ICT Uses, Resources and Mastery" were analyzed (Table 2). 
Table 1. List of items used in the model and methodology dimension.

\begin{tabular}{ccc}
\hline ID & Items & Code \\
\hline B.11 & Do you use/Have you ever used the pedagogical model Flipped Learning? \\
B.12 & Do you use/Have you ever used Project-Based Learning as an active methodology in the classroom? & FPL \\
B.13 & Do you use/Have you ever used Gamification as an active methodology in the classroom? & GML \\
\hline
\end{tabular}

Table 2. The relation between dimensions, indicators, and items.

\begin{tabular}{|c|c|c|}
\hline \multicolumn{3}{|r|}{ DIMENSION B. MATHEMATICS AND TEACHER TRAINING } \\
\hline ID & Code & Variables Used in Indicator B.2 Teaching practice \\
\hline B.23 & VED & I use a wide variety of teaching approaches in the classroom environment. \\
\hline B.24 & EAA & I valuate student learning in different ways. \\
\hline B.25 & ODA & I know how to organize and maintain the dynamics in the classroom. \\
\hline B.26 & EDP & I select teaching approaches effectively to guide students' thinking and learning in mathematics. \\
\hline B.27 & MTM & I consider my methodological techniques to be improved. \\
\hline ID & Code & Variables Used in Indicator B.3 Ratios \\
\hline B.32 & RPD & A high ratio in the classroom makes my teaching practice difficult \\
\hline \multicolumn{3}{|r|}{ DIMENSION C. ICT IN THE TEACHERS' ENVIRONMENT } \\
\hline ID & Code & Variables Used in Indicator C.1 ICT Training \\
\hline C.11 & FTP & I consider ICT training indispensable for personal use. \\
\hline C.13 & FTD & I consider ICT training to be essential for teaching practices. \\
\hline C.16 & FCM & What training have you received in Moodle content creation? \\
\hline C.17 & FCW & What training have you received in web page creation? \\
\hline C.18 & FMO & What training have you received in the handling of the Office package? \\
\hline C.19 & FRE & What training have you received in European Computer Driving License (ECDL)? \\
\hline C.20 & FOT & Have you received other ICT training? \\
\hline ID & Code & Variables Used in Indicator C.2 ICT and Teaching \\
\hline C.21 & TUM & I know technologies that I can use to understand and develop math content. \\
\hline C. 22 & TED & I select technologies that improve student learning in lessons. \\
\hline C. 24 & LTD & I can teach lessons that adequately combine mathematics, technology, and teaching approaches. \\
\hline C.26 & MDE & $\begin{array}{c}\text { For classroom teaching materials, I use strategies that combine content, technologies, and teaching } \\
\text { approaches that I have learned. }\end{array}$ \\
\hline C.27 & CCT & I take the use of ICT into account in the marking criteria. \\
\hline C. 28 & UHD & I use digital tools to carry out the assessment, tutoring, and/or monitoring of the students. \\
\hline C.29 & PCD & How many hours a week do you spend preparing digital content for your math classes? \\
\hline ID & Code & Variables Used in Indicator C.5 Communication and Collaboration \\
\hline C.51 & PFM & I participate in forums and chat with mathematical content. \\
\hline C.52 & $\mathrm{ACE}$ & I use tools for online communication with educational community agents: forums, instant messaging, chats... \\
\hline C.53 & UBA & I use blogs and wikis to develop online learning platforms for students. \\
\hline C.54 & $\mathrm{CIC}$ & $\begin{array}{l}\text { I share information and educational content in social networks and online communities and spaces } \\
\text { depending on the recipients. }\end{array}$ \\
\hline C.55 & DTT & In the department, we work in groups to develop content and strategies for teaching with ICT. \\
\hline C.56 & PPC & I participate in collaborative center projects related to digital technologies. \\
\hline \multicolumn{3}{|r|}{ DIMENSION D. ICT USES, RESOURCES AND MASTERY } \\
\hline ID & Code & Variables Used in Indicator D.3 ICT in the classroom \\
\hline D.32 & PDI & I use the tools or software on the digital interactive whiteboards to teach math. \\
\hline D.33 & EVA & I use virtual learning environments (Moodle, Webct, etc.) to teach math. \\
\hline D.34 & PEM & I use educational platforms (Tutor Factory, Wepack, etc.) to teach math. \\
\hline D.35 & SEA & I use author educational software (Cuadernia, Edilim, Jclic, etc.) to teach math. \\
\hline D.36 & OPT & In class we use computers, laptops, tablets, etc., to learn or review math. \\
\hline
\end{tabular}

Due to the small sample size, statistical power was analyzed. The results of the present study determined that the minimum sample size to obtain significant results was 
53 subjects [79]. On the other hand, for the given sample size, with a significance level of 0.05 , it was obtained that the power was 0.9781 . This means that if the study were repeated, the results would coincide in $97 \%$ of cases [80].

\section{Descriptive Analysis}

A preliminary analysis of the results allows us to differentiate the teachers' profile in relation to the use of the Flipped Learning pedagogical model and the Project-Based Learning and Gamification methodologies.

Table 3 shows that $77.05 \%$ of the mathematics teachers in the A.C. of Melilla state that they do not use the Flipped Learning pedagogical model. In addition, it is noteworthy that the value "A lot" was not scored. By gender, $77.78 \%$ of the male teachers rated the use of the model as "occasionally", with a negative tendency in the case of female teachers.

Table 3. Naïve Bayes classifier. A priori probabilities of Flipped Learning (FPL), Project-Based Learning (PBL), and Gamification (GML), and conditional probabilities.

\begin{tabular}{ccccc}
\hline \multicolumn{5}{c}{ FPL Do you use or have you ever used the pedagogical model Flipped Learning? } \\
\hline A Priori & Never & Occasionally & More than occasionally & A Lot \\
Probabilities & 0.77049180 & 0.14754098 & 0.08196721 & 0.0000000 \\
\hline \multicolumn{5}{c}{ Conditional Probabilities: GEN/FPL } \\
Gender & Never & Occasionally & More than occasionally & A Lot \\
Women & 0.4042553 & 0.2222222 & 0.0000000 & - \\
Men & 0.5957447 & 0.7777778 & 1.0000000 & - \\
\hline
\end{tabular}

PBL Do you use or have ever used Project-Based Learning as an active methodology in the classroom?

\begin{tabular}{|c|c|c|c|c|}
\hline $\begin{array}{c}\text { A Priori } \\
\text { Probabilities }\end{array}$ & $\begin{array}{c}\text { Never } \\
0.37704918\end{array}$ & $\begin{array}{c}\text { Occasionally } \\
0.49180328\end{array}$ & $\begin{array}{c}\text { More than occasionally } \\
0.01639344\end{array}$ & $\begin{array}{c}\text { A Lot } \\
0.11475410\end{array}$ \\
\hline \multicolumn{5}{|c|}{ Conditional Probabilities: GEN/PBL } \\
\hline Gender & Never & Occasionally & More than occasionally & A Lot \\
\hline Women & 0.3043478 & 0.4000000 & 1.0000000 & 0.1428571 \\
\hline Men & 0.6956522 & 0.6000000 & 0.0000000 & 0.8571429 \\
\hline \multicolumn{5}{|c|}{ GML Do you use or have ever used Gamification as an active methodology in the classroom? } \\
\hline A Priori & Never & Occasionally & More than occasionally & A Lot \\
\hline Probabilities & 0.16393442 & 0.67213115 & 0.04918033 & 0.11475410 \\
\hline \multicolumn{5}{|c|}{ Conditional Probabilities: GEN/GML } \\
\hline Gender & Never & Occasionally & More than occasionally & A Lot \\
\hline Women & 0.3902439 & 0.2000000 & 0.0000000 & 0.4285714 \\
\hline Men & 0.6097561 & 0.8000000 & 1.0000000 & 0.5714286 \\
\hline
\end{tabular}
scales. "Conditional Probabilities" is the disaggregation of the gender variable, conditional on the study variable.

As for the PBL methodology, it is relevant that $86.88 \%$ of teachers affirm that they use it "occasionally" or "never". By gender, among those who do not use this methodology, $69.56 \%$ are male. These data suggest an antagonistic polarization in the case of male teachers and a positive trend in the use of Project-Based Learning by female teachers in relation to inverted learning. On the other hand, among those who use this methodology, $85.71 \%$ of male teachers scored "a lot".

Regarding the use of Gamification as a methodological resource, it is worth noting that $67.21 \%$ of teachers use this resource "occasionally", $80 \%$ of whom are men. From the data obtained, it can be deduced that the ludic approach is hardly used in the mathematics teaching process since about $83.60 \%$ of the teachers of this discipline "occasionally" or "never" use Gamification as an active methodology in the classroom. However, there is a positive trend in the use of Gamification by male teachers compared to female teachers. 


\section{Results and Discussion}

The results of this study were analyzed from two different approaches. First, we employed a multidimensional analysis to evaluate, through the regressions, the impact of the different variables in the pedagogical model Flipped Learning and the methodologies Project-Based Learning and Gamification. The second analysis evaluated the associations between the most relevant variables of the study, because of their weight in the selected pedagogical choices and the general profile of the mathematics teacher in the A.C. of Melilla, according to the scores in the variables of greater impact.

\subsection{Analysis of the Study's Pedagogical Choices}

This first analysis sought to identify the study variables that had a significant influence on each of the study's pedagogical choices. To do this, a regression analysis was applied using numerical variables. In this way, an answer is given to RQ1: Which variables of the study had the most influence on the selection of the pedagogical model and the methodologies analyzed? Tables 3-5 illustrate the most significant variables and their level of correlation.

Table 4. Adjustment of the linear regression model for FPL (Do you use or have you ever used the pedagogical model Flipped Learning?).

\begin{tabular}{|c|c|c|c|c|}
\hline \multicolumn{5}{|c|}{ Coefficients: Items of Indicators B.2 Teaching Practice and B.3 Ratios } \\
\hline & Estimate & Std. Error & T Value & $\operatorname{Pr}(>|t|)$ \\
\hline Intercept & 4.1892 & 1.4829 & 2.825 & 0.016518 * \\
\hline VED & -2.2153 & 0.4713 & -4.701 & $0.000649 * * *$ \\
\hline EAA & -0.3571 & 0.1469 & -2.431 & 0.033338 * \\
\hline ODA & 2.3067 & 0.6160 & 3.745 & $0.003240 * *$ \\
\hline EDP & -0.6486 & 0.4063 & -1.596 & 0.138735 \\
\hline MTM & -0.2247 & 0.1295 & -1.735 & 0.110661 \\
\hline RPD & -0.3292 & 0.2117 & -1.555 & 0.148290 \\
\hline \multicolumn{5}{|c|}{$\begin{array}{l}\text { Residual standard error: } 0.4154 \text { on } 11 \text { degrees of freedom; Multiple R-squared: } 0.7055 \text {. Adjusted R-squared } \\
\text { 0.5449. F-statistic: } 4.392 \text { on } 6 \text { and } 11 \text { DF. } p \text {-value } 0.01656 .\end{array}$} \\
\hline \multicolumn{5}{|c|}{ Coefficients: Items of Indicator C.1 ICT Training } \\
\hline & Estimate & Std. Error & T Value & $\operatorname{Pr}(>|t|)$ \\
\hline Intercept & -0.14606 & 0.68819 & -0.212 & 0.836184 \\
\hline FTP & -0.50755 & 0.39967 & -1.270 & 0.232860 \\
\hline FTD & 0.30644 & 0.31425 & 0.975 & 0.352489 \\
\hline FCM & -0.08242 & 0.10247 & -0.804 & 0.439915 \\
\hline FCW & 0.54952 & 0.10131 & 5.424 & $0.000291^{* * *}$ \\
\hline FMO & 0.13839 & 0.25859 & 0.535 & 0.604214 \\
\hline FRE & 0.09641 & 0.09141 & 1.055 & 0.316349 \\
\hline FOT & -0.03441 & 0.09712 & -0.354 & 0.730480 \\
\hline \multicolumn{5}{|c|}{$\begin{array}{l}\text { Residual standard error: } 0.3588 \text { on } 10 \text { degrees of freedom; Multiple R-squared: } 0.8002 \text {. Adjusted R-squared: } \\
\qquad \begin{array}{l}0.6604 \text {. F-statistic: } 5.722 \text { on } 7 \text { and } 10 \text { DF. } p \text {-value } 0.007118 .\end{array}\end{array}$} \\
\hline \multicolumn{5}{|c|}{ Coefficients: Items of Indicator C.2 ICT and Teaching } \\
\hline & Estimate & Std. Error & T Value & $\operatorname{Pr}(>|t|)$ \\
\hline Intercept & -0.62662 & 0.43121 & -1.453 & 0.1768 \\
\hline TUM & -0.09739 & 0.19813 & -0.492 & 0.6336 \\
\hline TED & 0.06599 & 0.22567 & 0.292 & 0.7760 \\
\hline LTD & 0.50342 & 0.25590 & 1.967 & 0.0775 \\
\hline MDE & 0.15782 & 0.20447 & 0.772 & 0.4581 \\
\hline $\mathrm{CCT}$ & -0.19394 & 0.20069 & -0.966 & 0.3567 \\
\hline UHD & 0.30241 & 0.14491 & 2.087 & 0.0635 \\
\hline PCD & -0.35505 & 0.13576 & -2.615 & 0.0258 * \\
\hline
\end{tabular}

Residual standard error: 0.488 on 10 degrees of freedom; Multiple R-squared: 0.6305. Adjusted R-squared: 0.3719 . F-statistic: 2.438 on 7 and $10 \mathrm{DF}, p$-value 0.09762 .

Note. Signif. codes: $0^{\star * * * \prime} ; 0.001^{\star * * \prime} ; 0.01^{\star * \prime} ; 0.05^{\prime \prime} . ; 0.1^{\prime \prime} 1$; The most significant values are highlighted in bold in the table. 
Table 5. Adjustment of the linear regression model for PBL (Do you use or have you ever used Project-Based Learning as an active methodology in the classroom?).

\begin{tabular}{ccccc}
\hline \multicolumn{5}{c}{ Coefficients: Items of Indicators B.2 Teaching Practice and B.3 Ratios } \\
\hline & Estimate & Std. Error & T Value & $\operatorname{Pr}(>|\mathbf{t}| \mathbf{)}$ \\
\hline Intercept & 5.7703 & 1.8259 & 3.160 & $0.009077^{* *}$ \\
\hline VED & $\mathbf{- 2 . 7 6 1 6}$ & $\mathbf{0 . 5 8 0 3}$ & $-\mathbf{4 . 7 5 9}$ & $\mathbf{0 . 0 0 0 5 9 1} * * *$ \\
EAA & 0.2857 & 0.1809 & 1.580 & 0.142481 \\
ODA & 1.2311 & 0.7585 & 1.623 & 0.132867 \\
EDP & 0.2162 & 0.5003 & 0.432 & 0.674002 \\
MTM & $-\mathbf{0 . 4 2 5 1}$ & $\mathbf{0 . 1 5 9 5}$ & $-\mathbf{2 . 6 6 5}$ & $\mathbf{0 . 0 2 1 9 9 1}$ \\
RPD & -0.3903 & 0.2607 & -1.497 & 0.162529 \\
\hline
\end{tabular}

Residual standard error: 0.5115 on 11 degrees of freedom; Multiple R-squared: 0.8401. Adjusted R-squared: 0.7529 . F-statistic: 9.635 on 6 and 11 DF. $p$-value: 0.0007613

\begin{tabular}{ccccc}
\hline \multicolumn{5}{c}{ Coefficients: Items of Indicator C.5 Communication and Collaboration } \\
\hline & Estimate & Std. Error & T Value & $\operatorname{Pr}(>|\mathbf{t}| \mathbf{)}$ \\
\hline Intercept & -0.31802 & 0.54467 & -0.584 & 0.5711 \\
\hline PFM & 0.27880 & 0.20073 & 1.389 & 0.1923 \\
ACE & 0.02135 & 0.24142 & 0.088 & 0.9311 \\
UBA & -0.37700 & 0.28216 & -1.336 & 0.2085 \\
CIC & $\mathbf{0 . 5 8 1 0 1}$ & $\mathbf{0 . 2 2 5 4 7}$ & $\mathbf{2 . 5 7 7}$ & $\mathbf{0 . 0 2 5 7}$ \\
DTT & -0.15758 & 0.22202 & -0.710 & 0.4926 \\
PPC & $\mathbf{0 . 6 0 4 2 6}$ & $\mathbf{0 . 2 3 7 1 7}$ & $\mathbf{2 . 5 4 8}$ & $\mathbf{0 . 0 2 7 1}$ \\
\hline
\end{tabular}

Residual standard error: 0.7545 on 11 degrees of freedom. Multiple R-squared: 0.6521 . Adjusted R-squared: 0.4624 . F-statistic: 3.437 on 6 and 11 DF. $p$-value: 0.03663

\begin{tabular}{ccccc}
\hline \multicolumn{5}{c}{ Coefficients: Items of Indicator D.3 ICT in the Classroom } \\
\hline & Estimate & Std. Error & T Value & $\operatorname{Pr}(>|\mathbf{t}| \mathbf{)}$ \\
\hline Intercept & 0.6846 & 0.4630 & 1.479 & 0.1650 \\
\hline PDI & -0.2375 & 0.1817 & -1.307 & 0.2158 \\
EVA & 0.3000 & 0.1912 & 1.569 & 0.1426 \\
PEM & $-\mathbf{0 . 7 9 8 0}$ & $\mathbf{0 . 3 5 6 1}$ & $-\mathbf{2 . 2 4 1}$ & $\mathbf{0 . 0 4 4 7}$ \\
SEA & $\mathbf{1 . 1 7 5 7}$ & $\mathbf{0 . 4 0 6 4}$ & $\mathbf{2 . 8 9 3}$ & $\mathbf{0 . 0 1 3 5}$ \\
OPT & 0.1227 & 0.1865 & 0.658 & 0.5229 \\
\hline
\end{tabular}

Residual standard error: 0.7357 on 12 degrees of freedom. Multiple R-squared: 0.6392. Adjusted R-squared: 0.4889 . F-statistic: 4.252 on 5 and 12 DF. $p$-value: 0.0186

Note. Signif. codes: $0^{\prime * * * \prime} ; 0.001^{\star * * \prime} ; 0.01^{\prime * \prime} ; 0.05^{\prime} . \prime ; 0.1^{\prime \prime} 1$. The most significant values are highlighted in bold in the table.

The statistical analysis in Table 4 shows that the model is significant for indicator items B2, $(\mathrm{F}(6,11)=4.392, p<0.05) ; \mathrm{C} .1,(\mathrm{~F}(7,10)=5.722, p<0.05) ; \mathrm{C} 2,(\mathrm{~F}(7,10)=2.438$, $p<0.05)$, that is, it is a reliable predictor of the scores obtained in the selection of the FPL model. In addition, the present model with the items VED, EAA, and ODA of indicator B.2 Teaching Practice explains $54.49 \%$ of the variability of the response (R2). It is noteworthy that a single item, FCW of indicator C.1, ICT Training, predicts $66.04 \%$. In contrast, PCD of indicator C.2, ICT and Teaching, explains $37.19 \%$. These results suggest that $62.81 \%$ of the variance in the choice of the FPL model cannot be explained with the variables employed and that there must be other variables that also influence the results.

A more in-depth analysis of Table 4 shows that the largest number of items that correlate very significantly with this pedagogical model is 3: VED, EAA, and ODA, corresponding to indicator B.2 "Teaching Practice". Significant negative correlations are observed with teaching approaches, student assessment in a broad sense, and the time spent preparing digital content. In this sense, Sanchez-Rodriguez et al. (2017), argued that the overexertion in the preparation of the contents limits the use of the Flipped Learning model [32]. Furthermore, the results of "A high ratio in the classroom makes my teaching 
practice difficult", seem to confirm that it did not significantly impact the election of the Flipped Learning model. Contrary to this study's results, the literature postulates that this methodology favors the personalization of the teaching-learning processes [23].

Another result suggests that the scores of the items of the indicators C.1 "ICT Training" and C.2 "ICT and Teaching" had little weight in the Flipped Learning model. In fact, the findings of this study show a significant positive correlation only in the training for the creation of web pages. The rest of the training options for the mathematics teacher, the use of technologies for the preparation of contents, and for teaching practice in the classroom had little significant impact on the choice of this model. Furthermore, the data obtained for indicators C.5 "Communication and Collaboration" and D.3 "ICT in the Classroom" indicate a weak correlation between the mathematics teacher's use of technology for communication and collaboration among the educational community and the choice of the Flipped Learning model for teaching mathematics; however, the literature highlights the importance of technology for this methodology [22] by transferring the work of certain learning processes outside the classroom [20] and providing students with resources at any time for their learning [35]. Despite the positive assessment, some authors maintain that the effect on student and teacher satisfaction is moderate [31]. Other authors also highlighted other disadvantages associated with the teacher's perception and the students' capacity and economic resources [32].

The statistical analysis in Table 5 shows that the model is significant for the items of indicators B.2, $(\mathrm{F}(6,11)=9.635, p<0.05) ; \mathrm{C} .5,(\mathrm{~F}(6,11)=3.437, p<0.05) ; \mathrm{D} .3(\mathrm{~F}(5,12)=4.252$, $p<0.05)$, that is, it is a reliable predictor of the scores obtained in the election of the FPL model. It is noteworthy that the VED and MTM items of indicator B.2 "Teaching Practice" explain $75.29 \%$ of the variability of the response (R2). In contrast, CIC and PPT of indicator C.5 "Communication and Collaboration" predict 46.24\% and PEM and SEA of indicator D.3 "ICT in the Classroom" explain 48.89\%. These results suggest that around $50 \%$ of the variation in the choice of the FPL model cannot be explained by the variables used in indicators C.5 and D.3, and that, therefore, there must be other variables that also contribute.

An unexpected finding was that only two VED and MTM items of indicator B.2 "Teaching Practice" had a significant negative influence on Project-Based Learning. In addition, this study found that other factors associated with teaching practice did not have a significant weight in this methodology. These data should be interpreted with caution since they seem contradictory. On the other hand, a high ratio did not have a significant impact on this methodology either. Along the same lines as our findings, the literature postulates that the assessment of the Project-Based Learning against traditional methodology, even if it is positive, does not depend on the educational level or the ratio, although geographic factors, as well as available ICT resources and the commitment by teachers and students, do influence it [54].

However, the results of this study show that the participation in educational projects of the center, related to technologies and the exchange of information and digital content associated with the indicator C.5 "Communication and Collaboration" and the use of educational software to teach mathematics related to the indicator D.3 "ICT in the Classroom" has a significant influence on the choice of Project-Based Learning. Along the same lines, other authors maintain that Project-Based Learning integrates, in a practical way, values such as cooperation and organization [54]. This methodology can coexist with the traditional model, combining the teacher's expository work with practical collaborative work [56].

Nevertheless, our findings show that the use of online communication tools, blogs, and wikis to develop learning and educational platforms did not have a relevant weight in this methodology. Nor was there any significant correlation between this methodology with the use of Interactive Whiteboard tools or software or virtual learning environments (Moodle, WebCT...) to teach mathematics and the use of computers, laptops, and tablets, to learn or review mathematics. Several authors highlight that Project-Based Learning 
requires a high dedication to design and develop projects [60]. Consequently, there is a low level of creativity and originality in their work [57].

Likewise, the absence of items from the indicators C.1 "ICT Training" and C. 2 "ICT and Teaching" suggests that the ICT training and the use of technologies by the mathematics teacher for the preparation of contents and in their teaching practice in the classroom had little significant impact on the choice of this methodology. On the other hand, some authors maintain that this methodology represents, for the teacher, a high dedication, training, and time to improve self-efficacy [60]. Along the same lines, the importance of this methodology for teaching appears in the LOMCE curriculum, regarding the Spanish educational system, as a tool to promote learning to and help students to achieve competence in all subjects.

The statistical analysis in Table 6 shows that the model is significant for the items of indicators B.2 and B.3, $(\mathrm{F}(6,11)=3.543, p<0.05) ; \mathrm{C} 2,(\mathrm{~F}(7,10)=2.370, p<0.05)$; D.3, $(\mathrm{F}(5,12)=3.238, p<0.05)$, that is, it is a reliable predictor of the scores obtained in the election of the FPL model. It is noteworthy that the items VED and OAA of indicator B.2 "Teaching Practice" and RPD of indicator B.3 "Ratio", explain only $47.30 \%$ of the variability of the response (R2). On the other hand, the UHD of indicator C.2 "ICT and Teaching" predicts $36.07 \%$, and the EVA of Indicator D.3 "ICT in the Classroom" explains 36.69\%. These results suggest that around $60 \%$ of the variation in the choice of the GML model cannot be explained by the variables used in indicators B2, B3, C2, and D.3, and that, therefore, there must be other variables that also contribute.

Table 6. Adjustment of the linear regression model for GML (Do you use or have you ever used Gamification as an active methodology in the classroom?).

\begin{tabular}{ccccc}
\hline \multicolumn{5}{c}{ Coefficients: Items of Indicators B.2 Teaching Practice and B.3 Ratios } \\
\hline & Estimate & Std. Error & T Value & $\operatorname{Pr}(>|\mathbf{t}| \mathbf{)}$ \\
\hline Intercept & 10.7269 & 3.0542 & 3.512 & $0.00487^{* *}$ \\
VED & -3.6883 & $\mathbf{0 . 9 7 0 6}$ & -3.800 & $\mathbf{0 . 0 0 2 9 4}$ \\
EAA & -0.1887 & 0.3025 & -0.624 & 0.54549 \\
ODA & $\mathbf{3 . 4 8 2 3}$ & $\mathbf{1 . 2 6 8 8}$ & $\mathbf{2 . 7 4 5}$ & $\mathbf{0 . 0 1 9 0 7}$ \\
EDP & -1.8185 & 0.8369 & -2.173 & 0.05251 \\
MTM & -0.5336 & 0.2668 & -2.000 & 0.07082 \\
RPD & $\mathbf{- 1 . 0 5 8 2}$ & $\mathbf{0 . 4 3 6 1}$ & $\mathbf{- 2 . 4 2 7}$ & $\mathbf{0 . 0 3 3 6 0 *}$ \\
\hline
\end{tabular}

Residual standard error: 0.8555 on 11 degrees of freedom. Multiple R-squared: 0.659. Adjusted R-squared: 0.473 . F-statistic: 3.543 on 6 and 11 DF. $p$-value: 0.03335

\begin{tabular}{ccccc}
\hline \multicolumn{5}{c}{ Coefficients: Items of Indicator C.2 ICT and Teaching } \\
\hline Estimate & Std. Error & T Value & $\operatorname{Pr}(>|\mathbf{t}| \mathbf{)}$ \\
\hline Intercept & -0.2453 & 0.8327 & -0.295 & 0.7743 \\
TUM & -0.7349 & 0.3826 & -1.921 & 0.0837 \\
TED & 0.5027 & 0.4358 & 1.154 & 0.2755 \\
LTD & 0.4372 & 0.4942 & 0.885 & 0.3970 \\
MDE & 0.2100 & 0.3948 & 0.532 & 0.6064 \\
CCT & -0.5210 & 0.3876 & -1.344 & 0.2086 \\
UHD & $\mathbf{0 . 7 9 5 4}$ & $\mathbf{0 . 2 7 9 8}$ & $\mathbf{2 . 8 4 3}$ & $\mathbf{0 . 0 1 7 5} *$ \\
PCD & -0.3373 & 0.2622 & -1.286 & 0.2273
\end{tabular}

Residual standard error: 0.9423 on 10 degrees of freedom. Multiple R-squared: 0.6239. Adjusted R-squared: 0.3607 . F-statistic: 2.37 on 7 and 10 DF. $p$-value: 0.1046

\begin{tabular}{ccccc}
\hline \multicolumn{5}{c}{ Coefficients: Items of Indicator D.3 ICT in the Classroom } \\
\hline Estimate & Std. Error & T Value & $\operatorname{Pr}(>|\mathbf{t}| \mathbf{)}$ \\
\hline Intercept & -0.13256 & 0.57603 & -0.230 & 0.8219 \\
PDI & -0.02278 & 0.22607 & -0.101 & 0.9214 \\
EVA & $\mathbf{0 . 5 3 0 3 9}$ & $\mathbf{0 . 2 3 7 8 8}$ & $\mathbf{2 . 2 3 0}$ & $\mathbf{0 . 0 4 5 6 ^ { * }}$ \\
PEM & -0.50759 & 0.44300 & -1.146 & 0.2742 \\
SEA & 0.78711 & 0.50555 & 1.557 & 0.1455 \\
OPT & 0.05937 & 0.23204 & 0.256 & 0.8024 \\
\hline
\end{tabular}

Residual standard error: 0.9152 on 12 degrees of freedom. Multiple R-squared: 0.5743. Adjusted R-squared: 0.3969. F-statistic: 3.238 on 5 and 12 DF. $p$-value: 0.04428

Note. Signif. codes: $0.001^{\star * * \prime} ; 0.01^{\star * \prime} ; 0.05^{\prime \prime} . ; 0.1^{\prime \prime} 1$; The most significant values are highlighted in bold in the table. 
The present study's findings show that the use of tools for online communication, blogs, and wikis to develop learning platforms, as well as the use of educational software to teach mathematics related to indicator D.3 "ICT in the Classroom", did not have a relevant weight in this methodology; however, the use of educational platforms related to indicator D.3 "ICT in the Classroom" had a significant influence on the choice of Gamification. In this sense, the literature maintains that the teacher is fundamental in applying Gamification with the appropriate pedagogical criteria and obtaining a significant positive impact on the students' mathematical learning [70]; however, in our findings, the use of tools for online communication, blogs, and wikis to develop learning platforms and the use of educational software to teach mathematics did not have a relevant weight in this methodology.

No significant correlation was found between this methodology and the use of Interactive Whiteboard tools or software, virtual learning environments (Moodle, WebCT, etc.) to teach mathematics, and the use of computers, laptops, and tablets to learn or review mathematics. In this sense, some authors suggest applying this methodology without using technologies by applying the mechanics of the game to motivate and involve students [66]; however, some authors maintain that the divergence between the virtual and real worlds could limit the use of Gamification by teachers [77].

On the other hand, the absence of items from the C.1 "ICT Training" indicators suggests that whether the mathematics teacher had undergone ICT training had little significant impact on the choice of this methodology. Likewise, the data obtained related to indicator C.5 "Communication and Collaboration" could indicate that the use of technologies by the mathematics teacher for communication and collaboration among the educational community did not have a significant impact on Gamification either. Nevertheless, several authors argue that preservice teachers, trained in technologies, consider this methodology adequate for teaching mathematics [71]. On the other hand, the literature postulates that the use of this methodology is dependent upon the costs derived from the educational games and the technological resources necessary [68].

Based on the overall results, these data should be interpreted with caution since there are wide variations in the effect of some study variables on the choice of models and methodologies analyzed in this study. Contrary to expectations, the most determining value of teaching practice had a significant negative correlation in all methodologies. On the other hand, this study did not provide evidence of the significant influence of training on the Flipped Learning model, Project-Based Learning, and Gamification Methodologies, nor does it show the impact of technology used for educational purposes by the mathematics teacher as a determining factor. Several reasons could explain these surprising and apparently contradictory results: (1) due to the use of a traditional methodology for teaching mathematics by the mathematics teachers in the A.C. of Melilla; (2) due to a lack of knowledge on the part of teachers about the Flipped Learning model and active methodologies PBL and GML; (3) due to confusion about the terms used, which is associated with low digital competence.

In this sense, the mathematics teacher is fundamental and must be trained and updated on the use of tools and resources proper to mathematics teaching [5], establishing pedagogical links between contents and technologies through "instrumental genesis" [6]. It is a laborious process for the teacher that requires time [8]. In this sense, the teacher has the ability and responsibility to properly integrate ICTs into teaching mathematics (Forsstrom, 2019).

On the other hand, a global analysis shows that the indicators that most influenced the Flipped Learning model and the Project-Based Learning and Gamification methodologies were B.2 "Teaching Practice", followed by the dimension C.5 "Communication and Collaboration" and D.3 "ICT in the Classroom". The least impactful indicators were C.1 "ICT Training" and C.2 "ICT and Teaching". We can interpret these results as follows: the choice of the model and active methodologies by mathematics teachers in the A.C. of Melilla has been influenced by variables associated with teaching practice, communication, and collaboration through technologies and the use of ICTs in the classroom. On the other 
hand, variables related to technology training and ICT skills in teaching practice did not have a significant impact on the choice of the Flipped Learning model and Project-Based Learning and Gamification methodologies by mathematics teachers in the A.C. of Melilla. These results differ from some published studies, which affirm the fact that collaborative learning benefits from any of the active methodologies through technologies, as in the case of the Flipped Learning model for teacher training [34] and the students [35]. Nevertheless, the values of cooperation and collaboration are also integrated into Project-Based Learning [54,56] and Gamification [24].

\subsection{Analysis of the Study Variables}

An analysis of the relationship between the study variables with the greatest impact was conducted to evaluate the correlations between them, answering the research question RQ2: What relationship is observed between the variables that had the greatest weight? To obtain information about the existing correlations between the items of the study, a principal component analysis (PCA) was proposed, using a symmetrical biplot (Figure 1). The PCA allows the graphic visualization of the existing correlations in a multivariate analysis. For this purpose, the dimensionality was reduced, avoiding collinearity problems with minimal loss of information.

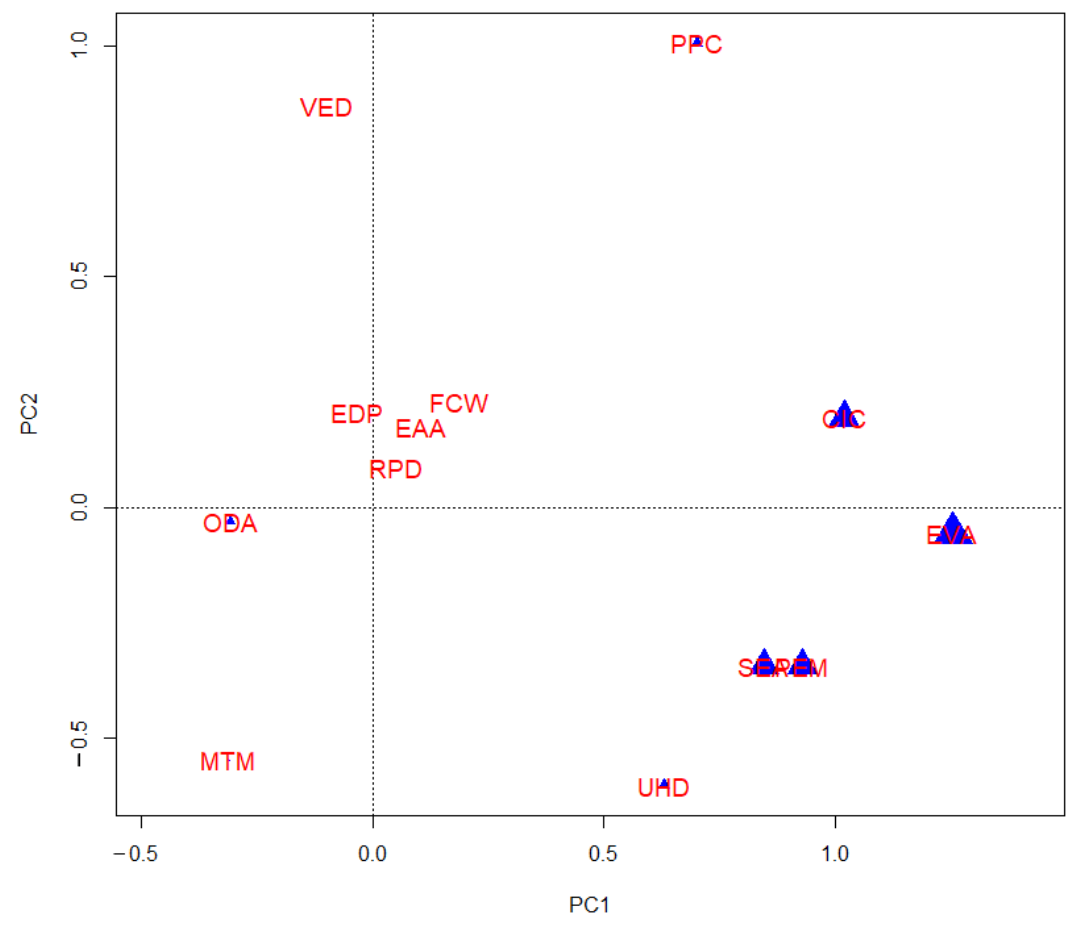

Figure 1. Principal component analysis (PCA) for the research items with the greatest impact on the active methodologies of the study.

Figure 1 shows that the variables ODA and MTM are negatively correlated in a significant way with RPD, EAA, FCW, PPC, and CIC. A possible interpretation of the results suggests that those teachers with a traditional approach to teaching are identified with the variables associated with teaching practice, scoring high on ODA and MTM and low on the items related to training and communication with ICT. In contrast, teachers who use ICTs give higher scores to the technological component of teaching. On the other hand, the significant negative correlation with RPD can be interpreted as a high ratio that can depend upon the use of active methodologies in the classroom.

VED and EDP variables are significantly negatively correlated with SEA, EVA, UHD, and PEM. These results reinforce the previous interpretation of the traditional and technological approaches to teaching by the mathematics teachers in the A.C. of Melilla. 
The variables PEM and SEA are strongly correlated. These results show that the mathematics teacher with technological competencies who uses educational platforms also uses educational software for teaching mathematics.

It is observed that the most important variables in the present study were EVA, PEM, SEA of indicator D.3, and CIC of indicator C.5. The less important indicators were ODA of indicator B.2, UHD of indicator C.2, and PPC of indicator C.5. The rest of the items, VED, EDP, EAA, RPD, MTM of indicator B.2, RPD of indicator B.3, and FCW of indicator C.1, had little relevance. These results suggest that the general perception of the A.C. of Melilla's mathematics teachers is that they consider themselves capable of adequately managing classroom dynamics, using digital resources to share educational information/content, employing software and educational platforms for teaching mathematics, and using digital tools for student evaluation/monitoring.

Numerous empirical studies emphasize that the advantages of learning through active methodologies affect the motivation, autonomy, and digital competence of mathematics students $[25,65,68,76]$. On the other hand, these methodologies can be integrated and complemented by expanding the pedagogical scope to improve the academic performance of students [78]. In contrast, other authors maintain that teaching experience correlates negatively with active methodological approaches [45].

In addition, to answer the research question RQ3 (What score did the mathematics teachers assign to the variables with the greatest impact?), a heat map was used with the most relevant variables (Figure 2). For this purpose, the algorithm selected a random subsample $(n=40)$.

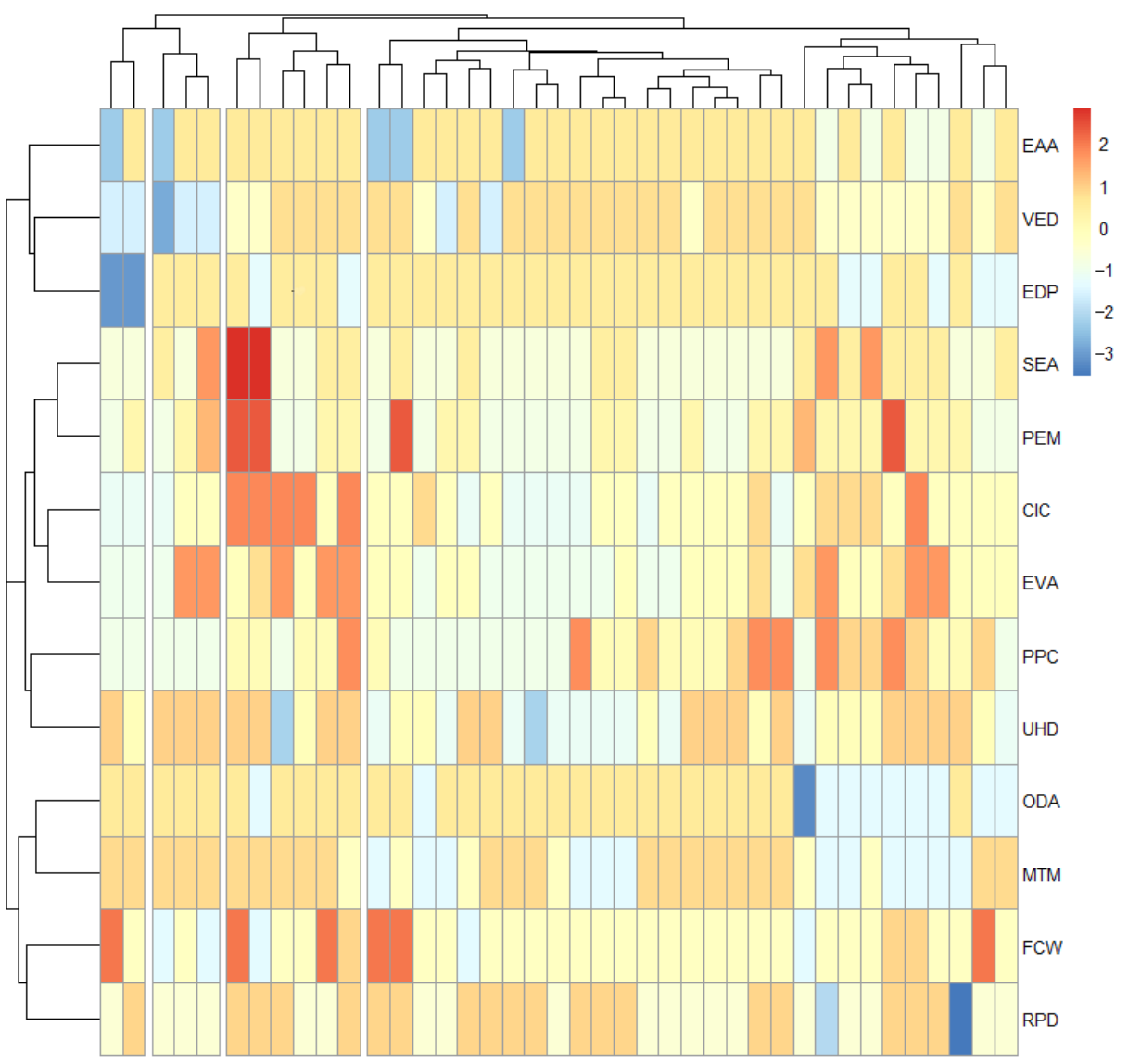

Figure 2. Heat map for the research variables with the greatest impact on the active methodologies of the study.

In order to create the heat map, the matrix data were scaled. The results were then visualized following a twofold process: the use of the R package "pheatmap" and, secondly, 
the cutree_rows not being specified and, instead, selected randomly. As can be seen, it is a heat map that incorporates, as a novelty, a hierarchical clustering analysis among the study participants, obviating their identities. We were not interested in performing a comparative analysis of the participants, but rather in seeing, for each of them, the variables that had the greatest impact on their response in order to contrast this with the findings.

This graph shows that the subsample responded in a general way with average scores in all the dimensions of the study; however, response peaks are observed for the variables SEA, PEM, CIC, EVA, PPC, and FCW.

Along the same lines, the subsample can be subdivided into four clusters (of 2, 3, 6 , and 29 individuals) according to the scores. In total, 5\% of teachers in the subsample present pedagogical preferences without a clear technological orientation; $7.5 \%$ of teachers in the subsample present a mixed profile between indicators B2 and D3; $15.0 \%$ of teachers in the subsample present a profile more oriented to the use of ICT in the classroom and to online communication and collaboration. The largest group, which accounted for $72.5 \%$ of the subsample, presents a mixed profile among the different technological indicators.

\section{Conclusions}

The following conclusions are presented regarding the Flipped Learning model, Project-Based Learning, and Gamification for mathematics teachers in the Autonomous City of Melilla. Despite the multiple advantages of the application of the Flipped Learning model [32], the Project-Based Learning model [54], and Gamification [71] methodologies, no clear indicators are observed. Some variables show a significant positive impact—such as the case of the exchange of information and content through online spaces (CIC), the participation and collaboration in center projects related to digital technologies (PPC), and the use of educational software to teach mathematics (SEA). The use of broad pedagogical approaches in the classroom (VED) is noted negatively. On the other hand, training in technologies did not show significant values, except for a significant positive impact of training in the creation of web pages.

In relation to the limitations, the data of the present study must be interpreted with caution, and they cannot be generalized since some variables of the same indicator were not aligned, showing disparate and apparently contradictory values. On the other hand, the small sample size is not a limitation due to the statistical power that guarantees the sample's significance. Among the strengths of this study, it should be noted that this is the first study that evaluates these three methodologies within the same sample. Equally noteworthy is the multivariate approach that identifies the most relevant indicators and the variables of the greatest weight in the three pedagogical practices. In addition, through the heat map, teachers can be classified into clusters and identified by their score on each item.

The lack of longitudinal studies that systematically analyze the impact of the study variables on the active methodologies analyzed is noteworthy. Future research could repeat the present study with another sample of different educational levels and including teachers of other subjects to evaluate the active methodologies. Pedagogical and technological advances are continuous and require an important effort by the teacher. In this sense, the heat map allows us to classify teachers into clusters and to identify them according to their responses. For this reason, among the practical applications of this study, we recommend periodic formation and training actions, as well as the updating of teachers' technological competencies and pedagogical and methodological strategies in the classroom for the didactics of mathematics. A standardized evaluation that certifies the digital competence of teachers is also recommended.

Author Contributions: Conceptualization, H.H.-M. (Hossein Hossein-Mohand) and M.G.-G.; methodology, H.H.-M. (Hossein Hossein-Mohand) and J.-M.T.-T.; software, H.H.-M. (Hassan HosseinMohand); validation, H.H.-M. (Hassan Hossein-Mohand), M.G.-G., and J.-M.T.-T.; formal analysis, M.G.-G. investigation, H.H.-M. (Hossein Hossein-Mohand); resources, H.H.-M. (Hossein HosseinMohand); data curation, H.H.-M. (Hossein Hossein-Mohand); writing-original draft preparation, H.H.-M. (Hossein Hossein-Mohand); writing_review and editing, H.H.-M. (Hossein Hossein- 
Mohand) and J.-M.T.-T.; visualization, A.C.-S.; supervision, M.G.-G., J.-M.T.-T., H.H.-M. (Hassan Hossein-Mohand), and A.C.-S. All authors have read and agreed to the published version of the manuscript.

Funding: This research received no external funding.

Institutional Review Board Statement: Not applicable.

Informed Consent Statement: Informed consent was obtained from all subjects involved in the study.

Data Availability Statement: Not applicable.

Conflicts of Interest: The authors declare no conflict of interest.

\section{References}

1. Chevallard, Y. La Transposición Didáctica. $2^{a}$ Reimp; Aique Grupo Editor: Buenos Aires, Argentina, 2005.

2. Trouche, L.; Monaghan, J.; Borwein, J.M. Didactics of Mathematics: Concepts, Roots, Interactions and Dynamics from France. In Tools and Mathematics; Springer: Berlin, Germany, 2016; pp. 219-256.

3. Vergnaud, G. Why the theory of conceptual fields? Infanc. Aprendiz. 2013, 36, 131-161. [CrossRef]

4. Verschaffel, L.; Schukajlow, S.; Star, J.; Van Dooren, W. Word problems in mathematics education: A survey. ZDM Math. Educ. 2020, 52, 1-16. [CrossRef]

5. Butlen, D.; Masselot, P. Challenges and modalities of formation for the teachers of the schools in didactics of mathematics. Can. J. Sci. Math. Technol. Educ. 2019, 19, 91-106. [CrossRef]

6. Hollebrands, K.; Okumus, S. Secondary mathematics teachers' instrumental integration in technology-rich geometry classrooms. J. Math. Behav. 2018, 49, 82-94. [CrossRef]

7. Lagrange, J.-B.; Artigue, M.; Laborde, C.; Trouche, L. Technology and mathematics education: A multidimensional study of the evolution of research and innovation. In Second International Handbook of Mathematics Education; Springer: Berlin/Heidelberg, Germany, 2003; pp. 237-269.

8. Trouche, L.; Gitirana, V.; Miyakawa, T.; Pepin, B.; Wang, C.Y. Studying mathematics teachers interactions with curriculum materials through different lenses: Towards a deeper understanding of the processes at stake. Int. J. Educ. Res. 2019, 93, 53-67. [CrossRef]

9. Siedel, H.; Stylianides, A.J. Teachers' Selection of Resources in an Era of Plenty: An Interview Study with Secondary Mathematics Teachers in England. In Research on Mathematics Textbooks and Teachers' Resources: Advances and Issues? Fan, L., Trouche, L., Qi, C., Rezat, S., Visnovska, J., Eds.; Springer: Berlin, Germany, 2018; pp. 119-144.

10. Trouche, L.; Gueudet, G.; Pepin, B. Open Educational Resources: A Chance for Opening Mathematics Teachers' Resource Systems. In Research on Mathematics Textbooks and Teachers' Resources: Advances and Issues; Springer: Berlin, Germany, 2018 ; pp. 3-27. [CrossRef]

11. Dolores Alvarez-Rodriguez, M.; del Carmen Bellido-Marquez, M.; Atencia-Barrero, P. Teaching though ICT in Obligatory Secundary Education. Analysis of online teaching tools. Red-Rev. Educ. A Distancia 2019. [CrossRef]

12. Rocha, K.d.M. Uses of Online Resources and Documentational Trajectories: The Case of Sesamath. In Research on Mathematics Textbooks and Teachers' Resources: Advances and Issues; Springer: Berlin, Germany, 2018; pp. 235-258. [CrossRef]

13. Lavicza, Z.; Prodromou, T.; Fenyvesi, K.; Hohenwarter, M.; Juhos, I.; Koren, B.; Diego-Mantecon, J.M. Integrating STEM-related Technologies into Mathematics Education at a Large Scale. Int. J. Technol. Math. Educ. 2020, 27, 3-11. [CrossRef]

14. Galimullina, E.; Ljubimova, E.; Ibatullin, R. SMART education technologies in mathematics teacher education-ways to integrate and progress that follows integration. Open Learn. 2020, 35, 4-23. [CrossRef]

15. Botuzova, Y.V. Experience of using ICT tools for teaching mathematical analysis to future teachers of mathematics. Inf. Technol. Learn. Tools 2020, 75, 153-169.

16. Forsstrom, S.E. Role of teachers in students' mathematics learning processes based on robotics integration. Learn. Cult. Soc. Interact. 2019, 21, 378-389. [CrossRef]

17. Donnelly-Hermosillo, D.F.; Gerard, L.F.; Linn, M.C. Impact of graph technologies in K-12 science and mathematics education. Comput. Educ. 2020, 146. [CrossRef]

18. Ramos, N.E.; Pineda, I.A.S. Mobiles technological environments as a learning space for mathematics and their value in the transformation of educational practices. Dialogo 2019, 21-36. [CrossRef]

19. Tovkanets, O.S. Strategic directions of information and communication technologies development in the high european school at the begining of the XXI century. Inf. Technol. Learn. Tools 2018, 66, 14-23. [CrossRef]

20. Moreno, D.; Palacios, A.; Barreras, A.; Pascual, V. An Assessment of the Impact of Teachers' Digital Competence on the Quality of Videos Developed for the Flipped Math Classroom. Mathematics 2020, 8, 148. [CrossRef]

21. Furse, C.M.; Ziegenfuss, D.H. A Busy Professor's Guide to Sanely Flipping Your Classroom: Bringing active learning to your teaching practice. IEEE Antennas Propag. Mag. 2020, 62, 31-42. [CrossRef] 
22. Pozo Sanchez, S.; Lopez Belmonte, J.; Moreno Guerrero, A.J.; Javier Hinojo-Lucena, F. Flipped learning and digital competence: A teaching connection necessary for its development in current education. Rev. Electron. Interuniv. Form. Profr. 2020, $23,127-141$. [CrossRef]

23. Colomo-Magana, E.; Soto-Varela, R.; Ruiz-Palmero, J.; Gomez-Garcia, M. University Students' Perception of the Usefulness of the Flipped Classroom Methodology. Educ. Sci. 2020, 10, 275. [CrossRef]

24. Garcia, F.Y.H.; Rangel, E.G.H.; Mera, N.A.G. Gamification in mathematics education: A systematic review. Telos-Rev. Interdiscip. Cienc. Soc. 2020, 22, 62-75. [CrossRef]

25. Lage, M.J.; Platt, G.J.; Treglia, M. Inverting the classroom: A gateway to creating an inclusive learning environment. J. Econ. Educ. 2000, 31, 30-43. [CrossRef]

26. Tucker, B. The flipped classroom. Educ. Next 2012, 12, 82-83.

27. Talbert, R. Inverted classroom. Colleagues 2012, 9, 7.

28. Coufal, K. Flipped Learning Instructional Model: Perceptions of Video Delivery to Support Engagement in Eighth Grade Math; Lamar University-Beaumont: Beaumont, TX, USA, 2014.

29. Talbert, R. Inverting the linear algebra classroom. Primus 2014, 24, 361-374. [CrossRef]

30. Ormell, C.P. Blooms Taxonomy and Objectives of Education. Educ. Res. 1974, 17, 3-18. [CrossRef]

31. Strelan, P.; Osborn, A.; Palmer, E. Student satisfaction with courses and instructors in a flipped classroom: A meta-analysis. J. Comput. Assist. Learn. 2020, 36, 295-314. [CrossRef]

32. Sanchez Rodriguez, J.; Ruiz Palmero, J.; Sanchez Vega, E. Flipped classroom. Keys for its implementation. Edmetic 2017, 6, 337-358. [CrossRef]

33. Bouchrika, I.; Harrati, N.; Wanick, V.; Wills, G. Exploring the impact of gamification on student engagement and involvement with e-learning systems. Interact. Learn. Environ. 2019. [CrossRef]

34. Trouche, L.; Rocha, K.; Gueudet, G.; Pepin, B. Transition to digital resources as a critical process in teachers' trajectories: The case of Anna's documentation work. ZDM Math. Educ. 2020. [CrossRef]

35. Bond, M. Facilitating student engagement through the flipped learning approach in K-12: A systematic review. Comput. Educ. 2020, 151. [CrossRef]

36. Muir, T. Self-determination theory and the flipped classroom: A case study of a senior secondary mathematics class. Math. Educ. Res. J. 2020. [CrossRef]

37. Wei, X.; Cheng, I.L.; Chen, N.-S.; Yang, X.; Liu, Y.; Dong, Y.; Zhai, X.; Kinshuk. Effect of the flipped classroom on the mathematics performance of middle school students. EtrD-Educ. Technol. Res. Dev. 2020. [CrossRef]

38. Lopez Belmonte, J.; Fuentes Cabrera, A.; Lopez Nunez, J.A.; Pozo Sanchez, S. Formative Transcendence of Flipped Learning in Mathematics Students of Secondary Education. Mathematics 2019, 7, 1226. [CrossRef]

39. He, J. Research and practice of flipped classroom teaching mode based on guidance case. Educ. Inf. Technol. 2020. [CrossRef]

40. Lundin, M.; Rensfeldt, A.B.; Hillman, T.; Lantz-Andersson, A.; Peterson, L. Higher education dominance and siloed knowledge: A systematic review of flipped classroom research. Int. J. Educ. Technol. High. Educ. 2018, 15. [CrossRef]

41. Weinhandl, R.; Lavicza, Z.; Houghton, T. Designing Online Learning Environments for Flipped Aproaches in Professional Mathematics Teacher Development. J. Inf. Technol. Educ. Res. 2020, 19, 315-337. [CrossRef]

42. Jeong, J.S.; Gonzalez-Gomez, D.; Yllana Prieto, F. Sustainable and Flipped STEM Education: Formative Assessment Online Interface for Observing Pre-Service Teachers' Performance and Motivation. Educ. Sci. 2020, 10, 283. [CrossRef]

43. Sarkar, N.; Ford, W.; Manzo, C. To flip or not to flip: What the evidence suggests. J. Educ. Bus. 2020, 95, 81-87. [CrossRef]

44. Ozudogru, M. The Factors Predicting Pre-Service Teachers' Achievement in Teacher Training Classrooms. Eurasian J. Educ. Res. 2020, 157-178. [CrossRef]

45. Andreu-Andrés, M.Á.; Labrador-Piquer, M.J. Formación del profesorado en metodologías y evaluación. Análisis cualitativo. Rev. Investig. Educ. 2011, 9, 236-245.

46. Lopez-Belmonte, J.; Elena Parra-Gonzalez, M.; Segura-Robles, A.; Pozo-Sanchez, S. Scientific Mapping of Gamification in Web of Science. Eur. J. Investig. Health Psychol. Educ. 2020, 10, 60. [CrossRef]

47. Silva, J.B.; Silva, I.N.; Bilessimo, S. Technological Structure for Technology Integration in the Classroom, Inspired by the Maker Culture. J. Inf. Technol. Educ. -Res. 2020, 19, 167-204. [CrossRef]

48. Moreno-Guerrero, A.-J.; Rodriguez-Jimenez, C.; Gomez-Garcia, G.; Ramos Navas-Parejo, M. Educational Innovation in Higher Education: Use of Role Playing and Educational Video in Future Teachers' Training. Sustainability 2020, 12, 2558. [CrossRef]

49. Acikgul, K.; Aslaner, R. Effects of Geogebra supported micro teaching applications and technological pedagogical content knowledge (TPACK) game practices on the TPACK levels of prospective teachers. Educ. Inf. Technol. 2020, 25, 2023-2047. [CrossRef]

50. Heard Kilpatrick, W. The Project Method (1918). Sch. Stud. Educ. 2020, 17, 136-149. [CrossRef]

51. Majó, F.; Baqueró, M. Los Proyectos Interdisciplinarios; Graó: Barcelona, Spain, 2014.

52. González, A.E. Las Competencias Básicas: Claves y Propuestas Para su Desarrollo en Los Centros; Graó: Barcelona, Spain, 2008; Volume 21.

53. Vos, P. "How Real People Really Need Mathematics in the Real World" Authenticity in Mathematics Education. Educ. Sci. 2018, 8, 195. [CrossRef] 
54. Chen, C.H.; Yang, Y.C. Revisiting the effects of project-based learning on students' academic achievement: A meta-analysis investigating moderators. Educ. Res. Rev. 2019, 26, 71-81. [CrossRef]

55. Bass, R. Disrupting ourselves: The problem of learning in higher education. Educ. Rev. 2012, 47, 23-33.

56. Sivia, A.; MacMath, S.; Novakowski, C.; Britton, V. Examining Student Engagement During a Project-Based Unit in Secondary Science. Can. J. Sci. Math. Technol. Educ. 2019, 19, 254-269. [CrossRef]

57. Chmelarova, Z.; Pasiar, L.; Vargova, D. The level of student's creativity and their attitude to the project-based learning. J. Educ. Sci. Psychol. 2020, 10, 3-15.

58. Mora, H.; Signes-Pont, M.T.; Fuster-Guillo, A.; Pertegal-Felices, M.L. A collaborative working model for enhancing the learning process of science \& engineering students. Comput. Hum. Behav. 2020, 103, 140-150. [CrossRef]

59. Ayerbe Lopez, J.; Perales Palacios, F.J. "Reinvent your city": Project-based learning for the improvement of environmental awareness in secondary school students. Ensen. Cienc. 2020, 38, 181-203. [CrossRef]

60. Choi, J.; Lee, J.-H.; Kim, B. How does learner-centered education affect teacher self-efficacy? The case of project-based learning in Korea. Teach. Teach. Educ. 2019, 85, 45-57. [CrossRef]

61. Rodríguez Gallego, M.R. El Aprendizaje-Servicio como estrategia metodológica en la Universidad. Rev. Complut. Educ. 2014, 25, 95-113. [CrossRef]

62. Zimmerling, E.; Hoellig, C.E.; Sandner, P.G.; Welpe, I.M. Exploring the influence of common game elements on ideation output and motivation. J. Bus. Res. 2019, 94, 302-312. [CrossRef]

63. Vanbecelaere, S.; Van den Berghe, K.; Cornillie, F.; Sasanguie, D.; Reynvoet, B.; Depaepe, F. The effects of two digital educational games on cognitive and non-cognitive math and reading outcomes. Comput. Educ. 2020, 143. [CrossRef]

64. Zumbach, J.; Rammerstorfer, L.; Deibl, I. Cognitive and metacognitive support in learning with a serious game about demographic change. Comput. Hum. Behav. 2020, 103, 120-129. [CrossRef]

65. Lo, C.K.; Hew, K.F. A comparison of flipped learning with gamification, traditional learning, and online independent study: The effects on students' mathematics achievement and cognitive engagement. Interact. Learn. Environ. 2020, 28, 464-481. [CrossRef]

66. Zainuddin, Z.; Chu, S.K.W.; Shujahat, M.; Perera, C.J. The impact of gamification on learning and instruction: A systematic review of empirical evidence. Educ. Res. Rev. 2020, 30. [CrossRef]

67. Ding, L. Applying gamifications to asynchronous online discussions: A mixed methods study. Comput. Hum. Behav. 2019, 91, 1-11. [CrossRef]

68. Bertram, L. Digital Learning Games for Mathematics and Computer Science Education: The Need for Preregistered RCTs, Standardized Methodology, and Advanced Technology. Front. Psychol. 2020, 11. [CrossRef]

69. Fuentes-Cabrera, A.; Parra-Gonzalez, M.E.; Lopez-Belmonte, J.; Segura-Robles, A. Learning Mathematics with Emerging Methodologies-The Escape Room as a Case Study. Mathematics 2020, 8, 1586. [CrossRef]

70. Verschaffel, L.; Depaepe, F.; Mevarech, Z. Learning Mathematics in Metacognitively Oriented ICT-Based Learning Environments: A Systematic Review of the Literature. Educ. Res. Int. 2019, 2019. [CrossRef]

71. Marin-Diaz, V.; Sampedro-Requena, B.E.; Munoz-Gonzalez, J.M.; Jimenez-Fanjul, N.N. The Possibilities of Gamifying the Mathematical Curriculum in the Early Childhood Education Stage. Mathematics 2020, 8, 2215. [CrossRef]

72. Lindberg, R.S.N.; Laine, T.H.; Haaranen, L. Gamifying programming education in K-12: A review of programming curricula in seven countries and programming games. Br. J. Educ. Technol. 2019, 50, 1979-1995. [CrossRef]

73. de Prado, M.G. Beneficios educativos y videojuegos: Revisión de la literatura española. Educ. Knowl. Soc. 2018, 19, 37-51. [CrossRef]

74. Ahijado, S.R.; Nicolás, A.M.B.; Alonso, T.J. El videojuego como recurso didáctico en el aula de música: Juegos educativos con E-Adventure y Muvizu. El Artist. 2017, 14, 13-29.

75. Fiorella, L.; Kuhlmann, S.; Vogel-Walcutt, J.E.J. Effects of Playing an Educational Math Game That Incorporates Learning by Teaching. J. Educ. Comput. Res. 2019, 57, 1495-1512. [CrossRef]

76. de Mendivil, I.S.M.; Crespo, R.G.; Gonzalez-Castano, A.; Ruiz, A.A.M.; Palma, L.O. A pedagogical tool based on the development of a computer application to improve learning in advanced mathematics. Rev. Esp. Pedagog. 2019, 77, 457-485. [CrossRef]

77. Shapiro, L.; Stolz, S.A. Embodied cognition and its significance for education. Theory Res. Educ. 2019, 17, 19-39. [CrossRef]

78. Huang, B.; Hew, K.F.; Lo, C.K. Investigating the effects of gamification-enhanced flipped learning on undergraduate students' behavioral and cognitive engagement. Interact. Learn. Environ. 2019, 27, 1106-1126. [CrossRef]

79. Trujillo-Torres, J.-M.; Hossein-Mohand, H.; Gomez-Garcia, M.; Hossein-Mohand, H.; Caceres-Reche, M.-P. Mathematics Teachers' Perceptions of the Introduction of ICT: The Relationship between Motivation and Use in the Teaching Function. Mathematics 2020, 8, 2158. [CrossRef]

80. Gomez-Garcia, M.; Hossein-Mohand, H.; Trujillo-Torres, J.M.; Hossein-Mohand, H. The Training and Use of ICT in Teaching Perceptions of Melilla's (Spain) Mathematics Teachers. Mathematics 2020, 8, 1641. [CrossRef] 